\title{
ECT2 Gene
}

National Cancer Institute

\section{Source}

National Cancer Institute. ECT2 Gene. NCI Thesaurus. Code C101783.

This gene plays a role in both GT Pase-mediated signaling and cellular stress responses. 